\title{
Fruit chemical composition of hazelnut cultivars grown in Portugal
}

Article

CITATIONS

6

6 authors, including:
READS

50
Ana Paula Silva

Universidade de Trás-os-Montes e Alto Douro

57 PUBLICATIONS 729 CITATIONS

SEE PROFILE

Fernando Santos

Universidade de Trás-os-Montes e Alto Douro 12 PUBLICATIONS 45 CITATIONS

SEE PROFILE
Alberto Santos

Universidade de Trás-os-Montes e Alto Douro

38 PUBLICATIONS 337 CITATIONS

SEE PROFILE

Berta Gonçalves

Universidade de Trás-os-Montes e Alto Douro

148 PUBLICATIONS 2,006 CITATIONS

SEE PROFILE 


\title{
Fruit chemical composition of hazelnut cultivars grown in Portugal
}

\author{
A.P. Silva ${ }^{\text {* }}$, A. Santos 1 , J. Cavalheiro ${ }^{2}$, C. Ribeiro $^{2}$, F. Santos ${ }^{1}$ and B. Gonçalves ${ }^{3}$ \\ ${ }^{1}$ CECEA - Centre for Agricultural Sciences and Engineering, University of Trás-os-Montes e Alto Douro, Apt. 1013, \\ 5001-801 Vila Real, Portugal; *e-mail: asilva@utad.pt; ${ }^{2}$ Department of Plant Science and Agricultural Engineering; \\ ${ }^{3}$ CETAV-Centre for Technological, Environmental and Live Studies. University of Trás-os-Montes e Alto Douro, Apt. \\ 1013, 5001-801 Vila Real, Portugal.
}

\begin{abstract}
Chemical composition (crude protein, crude fat, starch, neutral detergent fibre - NDF and free $\alpha$-amino acids) of six hazelnut cultivars (Butler, Ennis, Fertile de Coutard, Grossal, Merveille de Bollwiller and Segorbe) was investigated. Genotype significantly affected fruit

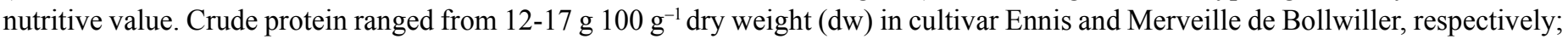

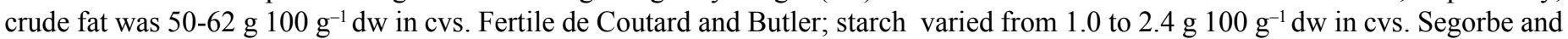
Butler; and NDF was 8-14 g $100 \mathrm{~g}^{-1} \mathrm{dw}$ in cvs. Merveille de Bollwiller and Ennis. Total free $\alpha$-amino acids content ranged from 144 $\mathrm{mg} 100 \mathrm{~g}^{-1} \mathrm{dw}$ (cv. Segorbe) to $413 \mathrm{mg} 100 \mathrm{~g} \mathrm{~g}^{-1} \mathrm{dw}$ (cv. Butler). The essential amino acids content varied between $23 \mathrm{mg} 100 \mathrm{~g} \mathrm{~g}^{-1} \mathrm{dw}$

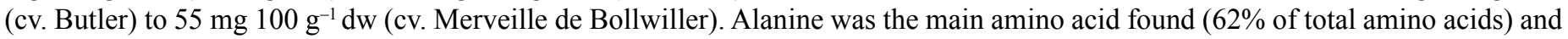
methionine was the lowest $(0.3 \%)$. Based on the available data on the phytochemical content of hazelnuts, including the data presented in this study, there is a high likelihood that this fruit will provide positive health benefits.
\end{abstract}

Key words: Crude fat, crude protein, free $\propto$-amino acids, neutral detergent fibre, proximate analysis, starch

\section{Introduction}

In recent years, nuts have become more important in human nutrition because of their potential health benefits. Epidemiological studies, in Framingham Massachusetts, USA, have shown that the frequency of nut intake was correlated with a risk reduction of coronary heart disease, atherosclerosis and some types of cancer by up to 50\% (Alpan et al., 1997; Richardson, 1997; Brehme, 2002). Moreover, Salas-Salvadó and Megias (2005) considered nuts as a natural functional healthy food. The recognition by the U.S. FDA that nuts must be regarded as "heart-healthy" foods gives a great input for the increase of the consumption of these fruits.

Consumers have become interested in food composition beyond the data usually available in standard composition tables (Souci et al., 1994; Holland et al., 1998). There is also increasing worldwide demand for non-meat protein sources with balanced amino acid profiles. As interest in nuts has been increased, it is important to evaluate the composition of these fruits commonly grown in each country. While it is obvious that hazelnuts have a positive role in human nutrition, it will not be easy to recognize which components have the more significant effects (Savage, 2001). However, Fraser et al. (1992) suggested that the health benefits of nuts are due to the synergistic effect between its constituents and enhanced complex biochemical interrelationships working together. Studies carried out by Shahidi et al. (2007) suggest that hazelnut and its byproducts, green leafy covers, hard shells and tree leaf, could potentially be considered as an excellent source of natural antioxidants. Most of the studies on the composition of hazelnut kernel have mainly focused on lipid content with little data on amino acid composition, starch, fibre and ash. According to Alasalvar et al. (2003), the good nutritional value of hazelnut is its amount of fibre that has an important protective effect against intestinal disorders, cholesterol and hypertension, among other effects. Gu et al. (2004) showed that hazelnut kernel contain significant concentration of proanthocyanidins that are known to have positive health effects.

Amino acids are important because they are the precursors of secondary plant metabolites and are involved in the production of compounds which directly or indirectly affect human health (Gomes and Rosa, 2000). Moreover, humans cannot synthesize ten amino acids, and these must be provided by the diet (Anderson $e t$ al., 1998). Free amino acids, are essential nonvolatile compounds involved in the overall taste and flavor of many foods having a considerable influence on the sensory characteristics of fruits, bitter, sour and sweet taste, affecting both quality and nutritional value (Fuke and Konosu, 1991).

Several studies indicated that the nut composition of hazelnut is affected by cultivar, harvest year, soil, irrigation and method of cultivation (Parcerisa et al., 1993; Parcerisa et al., 1994; Parcerisa et al., 1995; Amaral et al., 2006).

Therefore, a study was performed to evaluate the fruit quality of six hazelnut cultivars in field grown conditions in Portugal in relation to crude protein, crude fat, starch, neutral detergent fibre and free $\alpha$-amino acids for better knowledge of their composition vis-a-vis nutritional significance.

\section{Materials and methods}

Plant material and growth conditions: The study was carried out on 20-year-old plants of hazelnut (Corylus avellana L.) in an experimental plot near Vila Real, Northeast Portugal (41 ${ }^{\circ} 19^{\prime} \mathrm{N}$ 
and $7^{\circ} 44^{\prime} \mathrm{W}$; altitude $470 \mathrm{~m}$ above sea level) in 2005 . The climate is characterized as a transition from Csb to Csa (mesothermic climate with a partially dry summer) of Köpen. A plot of 75 plants representing eleven cultivars planted at $5 \times 3 \mathrm{~m}$ spacing on a Typic Dystrochrept silt loam soil and left unpruned was used for the study. The orchard was fertilized and periodically drip-irrigated (Santos et al., 1998). Nuts from six hazelnut cultivars: Butler, Ennis, Fertile de Coutard, Grossal, Merveille de Bollwiller and Segorbe were hand-picked from the ground at the beginning of the harvest in September, and kept unshelled in a refrigerator (2 ${ }^{\circ} \mathrm{C}$ ) until analyses were carried out.

Physical parameters: Yield per tree was recorded, and individual fruit and kernel weight estimated from 3 samples of 100 fruits. Yield per unit $\left(\mathrm{kg} \mathrm{m}^{-3}\right)$ was calculated. Canopy volume (v) was calculated for a prolate spheroid, a plant taller than wide, by the formula $v=4 / 3 \pi a b^{2}$, where $a=1 / 2$ of the tree canopy height and $\mathrm{b}=1 / 2$ of the tree canopy width (Lagerstedt and Painter, 1973).

Proximate analysis: Moisture content was determined using the Official Analytical Chemists Methods (AOAC, 1995). Representative samples of each cultivar were removed from the shell and the kernel was finely chopped, and ash content determined by incineration at $550{ }^{\circ} \mathrm{C}$ for $3 \mathrm{~h}$ in accordance with the AOAC method (1995). Crude protein (nitrogen x 6.25) was evaluated using the Kjeldahl procedure with selenium as a catalyst (AOAC, 1995). Crude fat was measured by extraction with petroleum ether in a Tecator Soxtec System (model HT1043) according to AOAC (1995). Starch was determined by enzymatic hydrolysis of starch to glucose as described by Salomonson et al. (1984). Neutral detergent fibre (NDF) was evaluated after extraction with the neutral detergent solution hydrolysis according to the procedures described by Van Soest et al. (1991).

Free $\alpha$-amino acids: The extraction and purification of free $\alpha$-amino acids were performed according to Gomes and Rosa (2000). Powdered freeze-dried tissues were extracted twice with boiling methanol $(90 \%)$ for 2 min under continuous homogenisation, centrifuged for $2 \mathrm{~min}$ at $6.25 \mathrm{~g}$, and the supernatant poured into a $10 \mathrm{~mL}$ volumetric flask. This step was repeated twice using methanol $(70 \%)$. Combined supernatants were made up to a final volume of $10 \mathrm{~mL}$ with methanol $(70 \%)$ and kept at $-18^{\circ} \mathrm{C}$ until analysis. Subsequently $2 \mathrm{~mL}$ of each extract was evaporated and resuspended in $2 \mathrm{~mL}$ of $0.1 \mathrm{M} \mathrm{HCl}$. Mini-columns of $1 \mathrm{~mL}$ (Chromabond from Macherey-Nagel) were connected to a solid phase extraction vacuum system (Gilson) and eluted with $0.5 \mathrm{~mL}$ of $0.1 \mathrm{M} \mathrm{HCl}$ before being filled up to $2 \mathrm{~cm}$ with a cation exchange resin, Dowex $\left(\mathrm{H}^{+}\right)$50WX8-499 (Sigma-Aldrich Chemicals, St Louis, MO, USA). The amino acids were loaded onto the columns and washed with $5 \mathrm{~mL}$ of $0.1 \mathrm{M} \mathrm{HCl}$. Free $\alpha$-amino acids were eluted with $4 \times 2.5 \mathrm{~mL}$ of $7 \mathrm{M} \mathrm{NH}_{3}$, pa (Merck, Darmstadt, Germany). After evaporation, the residue was resuspended in $0.3 \mathrm{~mL}$ of distilled water, filtered (Spartan $13,0.2 \mu \mathrm{m}$ ) and kept in vials at $-18^{\circ} \mathrm{C}$ until analysis. Amino acids were determined by HPLC using C18 column (Waters, Spherisorb S3ODS, id $4.6 \mathrm{~mm}) 150 \mathrm{~mm}$ length and a
UV/VIS detector set at $340 \mathrm{~nm}$, after precolumn derivatisation with o-phthaladehyde/2-mercaptoethanol. The mobile phase was made of two solvents: A $-350 \mathrm{mM} \mathrm{Na}_{2} \mathrm{HPO}_{4} \cdot 2 \mathrm{H}_{2} \mathrm{O}$ and $250 \mathrm{mM}$ propionic acid (1:1), acetonitrile and Milli-Q water (40:8:52); B - acetonitrile / methanol / water (30:30:40). With these solvents, a gradient was set (Table 1). Identification and quantification of detected amino acids were done against external standards after adjustment through regression lines.

Statistical analysis: Data analyses were performed as analysis of variance using the Super ANOVA software (1.1, Abacus Concepts Inc., 1991). Mean separations were made using Fisher's Protected LSD Test $(P=0.05)$, designed to allow all possible linear combinations of group means to be tested. All determinations were performed in triplicate.

\section{Results and discussion}

Physical parameters: The physical parameters (fruit and kernel weight, percent kernel and yield) were additionally measured to better characterize the fruits of the six cultivars that showed important visual differences. Physical parameters varied significantly among cultivars $(P<0.01)$ (Table 2$)$. Cv. Ennis presented the heaviest nuts, $64 \%$ higher than cv. Segorbe, which presented the lightest ones. The kernel weight followed the same trend, i.e., highest kernel weight was observed in cv. Ennis (1.8 $\mathrm{g})$ and the cv. Segorbe $(1.1 \mathrm{~g})$ had the lowest. These values were similar to the average data of the six cultivars recorded during fifteen years (Silva et al., 2005). The percent kernel was high in cvs. Segorbe, Butler, Ennis and Grossal ( $45 \%)$, and low in cv. Merveille de Bollwiller (39\%). Cv. Butler had the highest yield (Table 2).

Proximate analysis: Regarding chemical composition, crude protein, crude fat, starch and neutral detergent fibre (NDF) varied significantly among cultivars (Table 3 ). Crude protein

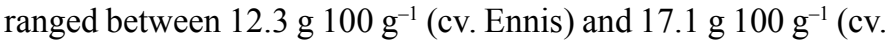
Merveille de Bollwiller). Hazelnuts, like other nuts, contain high levels of crude protein but few reports are available in literature (Alasalvar et al., 2003). These values were comparable with the levels recorded for six cultivars grown in Tarragona which ranged

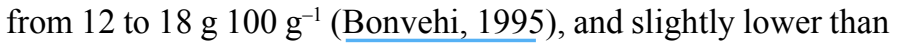
the values obtained for Butler, Ennis and Fertile de Coutard grown

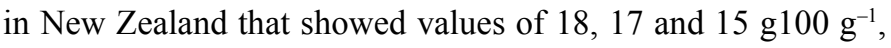
respectively (Savage and McNeil, 1998). Also, Alasalvar et al.

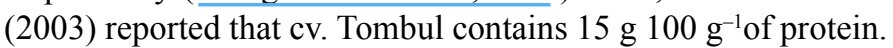
However, some cvs. like Yassi and Yuvarlak showed values as

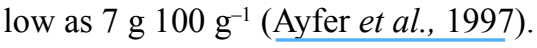

Generally, crude fat content of the samples was around $50 \%$

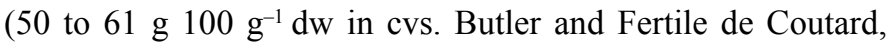
respectively) and was the predominant component of hazelnuts (Table 3). According to Richardson (1997) the oil content varied between $57 \% \mathrm{dw}$ in cv. Merveille de Bollwiller and $65 \% \mathrm{dw}$ in cvs. Tombul, Casina and Negret. Fat makes up $60-70 \%$ of the kernel, which is responsible for the high source of energy

Table 1. HPLC gradient for free $\alpha$-amino acid analysis

\begin{tabular}{lcccccccccc}
\hline Time $(\mathrm{min})$ & 0.0 & 9.5 & 11.0 & 13.6 & 20.4 & 23.4 & 25.4 & 32.0 & 34.0 & 37.0 \\
\hline Flow $\left(\mathrm{mL} \mathrm{min}^{-1}\right)$ & 1.3 & 1.3 & 1.3 & 1.3 & 1.3 & 1.3 & 0.8 & 0.8 & 1.3 & 1.3 \\
Solvent B (\%) & 0.0 & 11.0 & 12.0 & 20.0 & 45.0 & 50.0 & 60.0 & 100.0 & 0.0 & 0.0 \\
\hline
\end{tabular}


Table 2. Physical parameters of the fruits of the six hazelnut cultivars

\begin{tabular}{lcccc}
\hline Cultivar & Fruit weight $(\mathrm{g})$ & Kernel weight $(\mathrm{g})$ & Percent kernel $(\%)$ & Yield $\left(\mathrm{kg} \mathrm{m}^{-3}\right)$ \\
\hline Butler & $3.55 \pm 0.4 \mathrm{c}$ & $1.61 \pm 0.1 \mathrm{c}$ & $45.41 \pm 1.2 \mathrm{c}$ & $0.15 \pm 0.0 \mathrm{c}$ \\
Ennis & $3.86 \pm 0.2 \mathrm{~d}$ & $1.76 \pm 0.3 \mathrm{~d}$ & $45.53 \pm 3.1 \mathrm{c}$ & $0.05 \pm 0.0 \mathrm{a}$ \\
Fértile de Coutard & $3.36 \pm 0.2 \mathrm{c}$ & $1.45 \pm 0.2 \mathrm{~b}$ & $42.80 \pm 3.2 \mathrm{~b}$ & $0.09 \pm 0.0 \mathrm{~b}$ \\
Grossal & $2.44 \pm 0.2 \mathrm{a}$ & $1.12 \pm 0.1 \mathrm{a}$ & $45.85 \pm 2.9 \mathrm{c}$ & $0.08 \pm 0.0 \mathrm{~b}$ \\
Merveille de Bollwiller & $2.81 \pm 0.0 \mathrm{~b}$ & $1.09 \pm 0.0 \mathrm{a}$ & $38.57 \pm 2.5 \mathrm{a}$ & $0.14 \pm 0.0 \mathrm{c}$ \\
Segorbe & $2.35 \pm 0.1 \mathrm{a}$ & $1.08 \pm 0.1 \mathrm{a}$ & $46.09 \pm 3.1 \mathrm{c}$ & $0.08 \pm 0.0 \mathrm{~b}$ \\
$P$ & $<0.001$ & $<0.01$ & $<0.01$ & $<0.01$ \\
\hline
\end{tabular}

Different letters within one column denote statistically significant differences $(P<0.05)$ by ANOVA and Fisher's LSD test.

Values are average of three individual samples \pm standard deviation.

Table 3. Proximate analysis of the fruits of the six hazelnut cultivars

\begin{tabular}{lcccccc}
\hline Cultivar & $\begin{array}{c}\text { Crude protein } \\
\left(\mathrm{g} 100 \mathrm{~g}^{-1} \mathrm{dw}\right)\end{array}$ & $\begin{array}{c}\text { Crude fat } \\
\left(\mathrm{g} 100 \mathrm{~g}^{-1} \mathrm{dw}\right)\end{array}$ & $\begin{array}{c}\text { Starch } \\
\left(\mathrm{g} 100 \mathrm{~g}^{-1} \mathrm{dw}\right)\end{array}$ & $\begin{array}{c}\text { NDF } \\
\left(\mathrm{g} \mathrm{100} \mathrm{g}^{-1} \mathrm{dw}\right)\end{array}$ & $\begin{array}{c}\text { Moisture } \\
(\%)\end{array}$ & $\begin{array}{c}\text { Ash } \\
\left(\mathrm{g} \mathrm{100} \mathrm{g} \mathrm{dw}^{-1}\right)\end{array}$ \\
\hline Butler & $14.53 \pm 0.6 \mathrm{c}$ & $49.90 \pm 1.5 \mathrm{a}$ & $2.38 \pm 0.2 \mathrm{c}$ & $12.07 \pm 1.3 \mathrm{~d}$ & $4.03 \pm 0.1 \mathrm{c}$ & $2.82 \pm 0.2 \mathrm{a}$ \\
Ennis & $12.30 \pm 0.3 \mathrm{a}$ & $54.44 \pm 1.6 \mathrm{~b}$ & $1.90 \pm 0.2 \mathrm{~b}$ & $14.33 \pm 0.9 \mathrm{e}$ & $6.59 \pm 0.2 \mathrm{a}$ & $2.93 \pm 0.5 \mathrm{a}$ \\
Fertile de Coutard & $13.59 \pm 0.5 \mathrm{~b}$ & $61.15 \pm 3.1 \mathrm{~d}$ & $2.00 \pm 0.8 \mathrm{bc}$ & $9.60 \pm 0.9 \mathrm{~b}$ & $6.30 \pm 0.1 \mathrm{~b}$ & $2.55 \pm 0.5 \mathrm{a}$ \\
Grossal & $12.52 \pm 0.2 \mathrm{a}$ & $55.00 \pm 2.5 \mathrm{c}$ & $1.14 \pm 0.2 \mathrm{a}$ & $11.10 \pm 0.9 \mathrm{c}$ & $5.52 \pm 0.2 \mathrm{a}$ & $2.38 \pm 0.2 \mathrm{a}$ \\
Merveille de Bollwiller & $17.08 \pm 0.9 \mathrm{~d}$ & $56.18 \pm 2.3 \mathrm{c}$ & $2.16 \pm 0.3 \mathrm{c}$ & $8.05 \pm 2.0 \mathrm{a}$ & $4.58 \pm 0.2 \mathrm{~d}$ & $3.30 \pm 0.3 \mathrm{~b}$ \\
Segorbe & $14.68 \pm 0.9 \mathrm{c}$ & $53.75 \pm 1.7 \mathrm{~b}$ & $1.00 \pm 0.0 \mathrm{a}$ & $9.96 \pm 1.9 \mathrm{~b}$ & $4.88 \pm 0.2 \mathrm{c}$ & $2.67 \pm 0.5 \mathrm{a}$ \\
$P$ & $<0.001$ & $<0.001$ & $<0.01$ & $<0.001$ & $<0.001$ & $<0.01$ \\
\hline
\end{tabular}

Different letters within one column denote statistically significant differences $(P<0.05)$ by ANOVA and Fisher's LSD test.

Values are average of three individual samples \pm standard deviation.

(Parcerisa et al., 1993; Bota et al., 1997; Pala and Ünal, 1997), where approximately $80 \%$ of the calories of nuts are derived from the fat (Salas-Salvadó and Megias, 2005). However, according to Richardson (1997), nuts are low in saturated fatty acids and rich in monounsaturated and polyunsaturated fatty acids and have no cholesterol which is beneficial in reducing the risk of circulatory and coronary diseases.

As referred before, differences among the hazelnut cultivars were observed based on the starch content (Table 3), but all cultivars showed relatively low values of the total starch. Moreover, cv. Butler had two times more starch than cv. Segorbe (2.4 and 1.0 g $100 \mathrm{~g}^{-1} \mathrm{dw}$, respectively). Savage and McNeil (1998) also

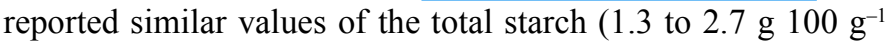
$\mathrm{dw})$ in the kernels of six cultivars grown in New Zealand. The low starch content (little transformation of starch into sugar during storage) is associated with low state of hydration and when storage conditions are good, is responsible for the long storage period of hazelnuts.

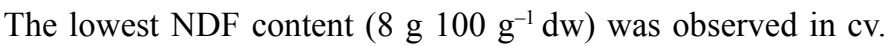
Merveille de Bollwiller, whilst cv. Ennis showed the highest (14 g $100 \mathrm{~g}^{-1} \mathrm{dw}$ ) (Table 3). These cultivars had higher values than those reported in other hazelnut studies with different cultivars (Lintas and Cappeloni, 1992). Savage and McNeil (1998) and Megias-Rangil et al. (2004) indicated one of the human benefits of hazelnuts is their fibre content. Alasalvar et al. (2003) assumed that eating $\sim 200 \mathrm{~g}$ of Tombul hazelnuts per day is adequate to supply $100 \%$ of the total fibre requirement for adults. Although, cv. Ennis nuts seem to be the best for the preparation of fibrebased foods, more data are needed to confirm this.

Ash and moisture were also determined and these parameters varied among cultivars (Table 3 ). The average ash content was found to be $2.77 \%$, parallel to the results of Pala et al. (1996) and Köksal et al. (2006). The minimum and maximum values, based

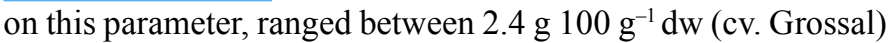

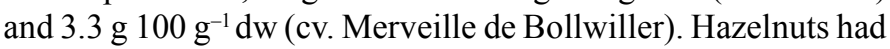

very low moisture content (lower than $7 \%$ ), which is an advantage for adequate storage.

Free $\alpha$-amino acids: Total free $\alpha$-amino acids and essential amino acids were significantly $(P=0.001)$ different among cultivars (Table 4). Total amino acid contents ranged from 144 to 413 mg $100 \mathrm{~g}^{-1} \mathrm{dw}$ in cvs. Segorbe and Butler, respectively. These results are different from those obtained by Silva et al. (2005) in the years 2001 and 2002, which emphasises the dependence between the total amino acid and weather. Alasalvar et al. (2003) considered that the content of amino acids in hazelnuts varies according to cultivars, growing seasons, environmental factors and maturity. Essential amino acids content ranged from 22 to $55 \mathrm{mg} 100 \mathrm{~g}^{-1} \mathrm{dw}$ in cvs. Butler and Merveille de Bollwiller, respectively, indicating that hazelnuts are a good source of these compounds (Table 4).

Table 4. Amino acid content (mg $100 \mathrm{~g}^{-1} \mathrm{dw}$ ) in the fruits of the six hazelnut cultivars

\begin{tabular}{lcc}
\hline Cultivar & $\begin{array}{c}\text { Total essential amino } \\
\text { acids }\end{array}$ & $\begin{array}{c}\text { Total free } \alpha- \\
\text { amino acids }\end{array}$ \\
\hline Butler & $22.23 \pm 0.2 \mathrm{a}$ & $413.46 \pm 11.1 \mathrm{e}$ \\
Ennis & $48.94 \pm 1.2 \mathrm{~d}$ & $237.91 \pm 10.2 \mathrm{c}$ \\
Fértile de Coutard & $23.13 \pm 2.1 \mathrm{a}$ & $390.12 \pm 15.3 \mathrm{e}$ \\
Grossal & $27.65 \pm 0.5 \mathrm{bc}$ & $185.26 \pm 10.9 \mathrm{~b}$ \\
Merveille de Bollwiller & $55.20 \pm 1.9 \mathrm{e}$ & $330.65 \pm 12.6 \mathrm{~d}$ \\
Segorbe & $30.91 \pm 0.9 \mathrm{c}$ & $144.17 \pm 10.2 \mathrm{a}$ \\
$P$ & $<0.001$ & $<0.001$ \\
\hline
\end{tabular}

Different letters within one column denote statistically significant differences $(P<0.05)$ by ANOVA and Fisher's LSD test.

Table 5 depicts content of 16 amino acids identified in the 6 hazelnut cultivars, namely, L-alanine (Ala), L-asparagine (Asn), L-aspartic acid (Asp), glycine (Gly), L-glutamic acid (Glu), Lglutamine (Gln), L-serine (Ser), and the essential amino acids: L-arginine (Arg), L-histidine (His), L-isoleucine (Ile), L-leucine (Leu), L-methionine (Met), L-threonine (Thr), L-phenylalanine (Phe), L-tyrosine (Tyr) and L-valine (Val). Specifically, only the 
amino acids, histidine and methionine were not affected by the cultivar. As in previous studies (Rennie, 1995; Savage and McNeil, 1998; Alasalvar et al., 2003; Köksal et al., 2006) we also did not detect any tryptophan, even though some nutritional databases report this amino acid in hazelnuts (Souci, 1994; Holland et al., 1998).

In all hazelnut cultivars studied Ala was the most common non-essencial amino acid, which was significantly different $(P<0.001)$ among the cultivars, and represented $62 \%$ of total free

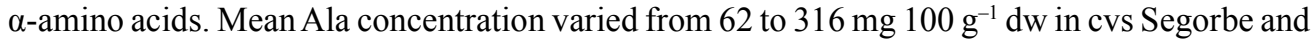
Butler, respectively. Apart from an important source of energy, Ala, a non-polar amino acid, is responsible for an increase in immune responses and takes part in the metabolism of sugars and organic acids (Rennie, 1995). Other important amino acids included Gln that varied from 13.96

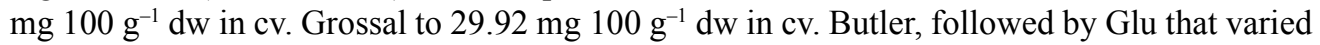
between $7.29 \mathrm{mg} 100 \mathrm{~g}^{-1} \mathrm{dw}$ in cv. Fertile de Coutard and $30.5 \mathrm{mg} 100 \mathrm{~g}^{-1} \mathrm{dw}$ in cv. Merveille de Bollwiller. A group of seven amino acids, five of them essential, had values lower than 10 mg $100 \mathrm{~g}^{-1} \mathrm{dw}$ : Met, His, Ser, Gly, Phe and Ile. Specifically, Met concentration was the lowest among the amino acids $(0.3 \%$ of total free $\alpha$-amino acids) determined (Table 5). Köksal et al. (2006) also considered Met the most insignificant amino acid. In general, the fruits of cv. Butler (American origin) had the highest amino acid content and was two times greater than the fruits of cvs. Grossal and Segorbe (Spanish origin). However, the values obtained in diverse studies were different for the amount and the relative proportion of each amino acid (Alasalvar et al., 2003; Köksal et al., 2006).

Our data confirm that hazelnuts are a rich source of a number of important nutrients that can have a very positive effect on human health. The composition of hazelnut kernels, particularly total and individual free $\alpha$-amino acids, crude protein, crude fat, starch and neutral detergent fibre are strongly affected by cultivar. The major amino acid found was alanine, representing $60 \%$ of the total free $\alpha$-amino acids, and methionine was the lowest (1.5\% of the total free $\alpha$ amino acids).

\section{References}

A.O.A.C. 1995. Official Methods of Analysis. Association of Official Analytical Chemists. 16th Edn., VA, USA.

Alasalvar, C., F. Shahidi, C.M. Liyanapathirana and T. Ohshima, 2003. Turkish Tombul hazelnut (Corylus avellana L.). 1. Compositional characteristics. J. Agric. Food Chem., 51: 3790-3796.

Alpan, E., M. Pala, F. Açkurt, and T. Yilmaz, 1997. Nutritional composition of hazelnuts and its effects on glucose and lipid metabolism. Acta Hortic., 445: 305-310.

Amaral, J.S., S.C. Cunha, A. Santos, M.R. Alves, R.M. Seabra and B.P.P. Oliveira, 2006. Influence of cultivar and environmental conditions on the triacylglycerol profile of hazelnut (Corylus avellana L.). J. Agric. Food Chem., 54: 449-456.

Anderson, P.C., K. Hill, Dw Gorbet and B.V. Brodbeck, 1998. Fatty acid and amino acid profiles of selected peanut cultivars and breeding lines. J. Food Comp. Anal., 11: 100-111.

Ayfer, M., R. Turk and A. Eris, 1997. Chemical composition of "Degirmendere" hazelnut and its importance in human nutrition. Acta Hortic., 445: 51-53.

Bonvehi, J.S. 1995. A chemical study of the protein fractions of Tarragona hazelnuts (Corylus avellana, L.). Z. Lebensm. Unters Forsh., 201: 371-374.

Bota, R., C. Gianotti and G. Me, 1997. Kernel quality in hazelnut cultivars and selections analysed for sugars, lipids and fatty acid composition. Acta Hortic., 445: 319-326.

Brehme, U. 2002. Significance of nuts in the daily diet for prevention of cardiovascular diseases. Ernährungs-Umschau, 49: 44-48.

Fraser, G.E., J. Sabaté, W.L. Beeson and T.M. Strahan, 1992. A possible protective effect of nut consumption on risk of coronary heart disease. Arch. Intern. Med., 152: 1416-1424.

Fuke, S. and S. Konosu, 1991. Taste-active components in some foods: a review of Japanese research. Physiol. Behav., 49: 863-868.

Gomes, M.H. and E. Rosa, 2000. Free amino acid composition in primary and secondary inflorescences of 11 broccoli (Brassica oleracea var itálica) cultivars and its variation between growing seasons. $J$. Sci. Food Agric., 81: 295-299.

Gu, L., M.A. Kelm, J.F. Hammerstone, G. Beecher, J. Holden, D. Haytowitz, S. Gebhardt, R.L. Prior, 2004. Concentrations of proanthocyanidins in common foods and estimation of normal consumption. J. Nutrition, 134: 613-617.

Holland, B., A.A. Welch, I.D. Unwin, D.H. Buss, A.A. Paul and D.A.T. Southgate, 1998. The Composition of Foods. McCance and Widdowson's (eds), Royal Society of Chemistry: London.

Köksal, A., A. Nevzat, A. Şimşek, N. Güneş, 2006. Nutrient composition of hazelnut cultivated in Turkey. Food Chem., 99: 509-515. 
Lagerstedt, H.B. and J.H. Painter, 1973. A comparison of filbert training to tree and bush forms. HortScience, 8: 390 .

Lintas, C. and M. Cappeloni, 1992. Dietary fiber content of Italian fruit and nuts. J. Food Compos. Anal., 5: 146-151.

Megias-Rangil, I., P. Garcia-Lorda, M. Torres-Moreno, M. Bullo and J. Salas-Salvado, 2004. Nutrient content and health effects of nuts. Arch. Latinoam. Nutr., 54: 83-86.

Pala, M. and M. Ünal, 1997. Application of supercritical extraction to production of low-calorie hazelnut. Acta Hortic., 445: 311-317.

Pala, M., F. Açkurt, M. Löker, M. Yildiz and S. Ömeroglu, 1996. Composition and nutritional evaluation of different hazelnut varieties. Turk. J. Agric. For., 20: 43-48.

Parcerisa, J., M. Rafecas, A.I. Castellote, R. Codony, A. Ferràn, J. Garcia, A. Lopez, A. Romero and R. Boatella, 1994. Influence of variety and geographical origin on the lipid fraction of hazelnuts (Corylus avellana L.) from Spain: II Triglyceide composition. Food Chem., 50: 245-249.

Parcerisa, J., M. Rafecas, A.I. Castellote, R. Codony, A. Ferràn, J. Garcia, C. Gonzalez, A. Lopez, A. Romero and R. Boatella, 1995. Influence of variety and geographical origin on the lipid fraction of hazelnuts (Corylus avellana L.) from Spain: III Oil stabily, tocopherol content and some mineral contents (Mn, $\mathrm{Fe}, \mathrm{Cu}$ ). Food Chem., 53: 71-74.

Parcerisa, J., R. Boatella, R. Codony, A. Ferràn, J. Garcia, A. Lopez, M. Rafecas and A. Romero, 1993. Influence of variety and geographical origin on the lipid fraction of hazelnuts (Corylus avellana L.) from Spain: I. Fatty acid composition. Food Chem., 48: 411-414.

Rennie, M. 1995. Amino Acids. San Francisco: Allergy Research Group of Smart. http//www.nal.usda.gov/fnic/foodcomp/index.html>.
Richardson, D.G. 1997. The health benefits of eating hazelnuts: implications for blood lipid profiles, coronary heart disease and cancer risks. Acta Hortic., 445: 295-300.

Salas-Salvadó, J. and I. Megias, 2005. Health and tree nuts: Scientific evidence of disease prevention. Acta Hortic., 686: 507-513.

Salomonson, A., O. Theander and E. Westwrlund, 1984. Chemical characterisation of some Swedish cereal whole meal and bran fractions. Swedish J. Agric. Res., 14: 111-117.

Santos, A.A., A.P. Silva and E. Rosa, 1998. Shoot growth and yield of hazelnut (Corylus avellana, L.) and influence of climate: Ten years of observations. J. Hortic. Sci. Biotech., 73: 145-150.

Savage, G.P. 2001. Chemical composition of walnuts (Juglans regia L.) grown in New Zealand. Plant Food Hum. Nutr., 56: 75-82.

Savage, G.P. and D.L. McNeil, 1998. Chemical composition of hazelnuts (Corylus avellana L.) grown in New Zealand. Int. J. Food Sci. Technol., 49: 199-203.

Shahidi, F., C. Alasalvar and C.M. Liyana-Pathirana, 2007. Antioxidant phytochemicals in hazelnut kernel (Corylus avellana L.) and hazelnut byproducts. J. Agric. Food Chem., 55: 1212-1220.

Silva, A.P., F. Santos, E. Rosa and A. Santos, 2005. Effect of cultivar and year on the quality of hazelnut fruits (Corylus avellana L.). Acta Hortic., 686: 469-475.

Souci, S.W., W. Fachmann and H. Kraut, 1994. Food Composition and Nutrition Tables. 5th edn. Medpharme Scientific Publishers: Stuttgart.

Van Soest, P., J. Robertson and B.A. Lewis, 1991. Methods for dietary, fiber, NDF and non-starch polysaccharides in relation to animal nutrition. J. Dairy Sci., 74: 3583-3597. 